\title{
LANSIA DALAM MENGHADAPI BENCANA DI KOTA BOGOR
}

\author{
Suwarningsih $^{1}$, Luvita Nurwidiasmara ${ }^{2}$, Zakiyah Mujahidah ${ }^{3)}$ \\ Program Studi S1 Keperawatan Fakultas Kesehatan Universitas MH. Thamrin \\ suwarningsih41@gmail.com
}

\begin{abstract}
ABSTRAK
Bencana merupakan situasi yang tidak terduga, dimana dalam kondisi tersebut bisa terjadi kerusakan, kematian atau kehilangan harta benda. Pengetahuan dan sikap lansia dalam menghadapi bencana sangat dibutuhkan untuk mencegah terjadinya korban jiwa. Penelitian ini dilakukan bertujuan untuk mengetahui hubungan pengetahuan dan sikap lansia dalam menghadapi bencana. Metode penelitian ini menggunakan desain cross sectional. Penelitian dilakukan di wilayah Kampung Babakan Peundeuy Kota Bogor Jawa Barat. Hasil penelitian didapatkan ada hubungan bermakna antara pengetahuan dan sikap ( $\mathrm{p}$ value $=0.004$ ) pada lansia dalam menghadapi bencana. Saran untuk penelitian ini yaitu diharapkan adanya program peningkatan pengetahuan dengan mengadakan pelatihan dan pemberdayaan lansia dalam menghadapi bencana di Kota Bogor.
\end{abstract}

Kata Kunci: Bencana, Lansia, Pengetahuan, Sikap

\section{PENDAHULUAN}

Indonesia merupakan salah satu negara yang rawan terhadap kejadian bencana, kondisi tersebut didukung dengan keadaan geografis, karena secara geografis Indonesia merupakan negara kepulauan yang terletak pada pertemuan empat lempeng tektonik yaitu lempeng Benua Asia, Benua Australia, lempeng Samudera Hindia dan Samudera Pasifik (BNPB, 2017). Bencana merupakan suatu peristiwa yang sangat mengancam kehidupan masyarakat, baik yang disebabkan oleh faktor alam maupun faktor non alam (BNPB, 2010). Tahun 2012 di seluruh dunia telah terjadi bencana alam sebanyak 357 kali yang menyebabkan 122.900.000 korban dan lebih dari 9.655 orang meninggal dunia dengan kerugian mencapai 157.300.000.000 akibat kerusakan yang terjadi. Setelah negara Cina, Amerika Serikat dan Filipina, Indonesia menjadi nomor urut ke tiga dalam kategori sering terkena bencana alam (CRED, 2012).

Bencana merupakan situasi yang kedatangannya tidak terduga oleh kita sebelumnya, dimana dalam kondisi itu bisa terjadi kerusakan, kematian atau kehilangan harta benda. Bencana dapat terjadi melalui proses yang panjang atau situasi tertentu dalam waktu yang sangat cepat tanpa adanya tanda-tanda. Bencana sering menimbulkan kepanikan masyarakat dan menyebabkan penderitaan dan kesedihan yang berkepanjangan, seperti luka, kematian, tekanan ekonomi akibat hilangnya usaha atau pekerjaan dan kekayaan harta benda, kehilangan anggota keluarga serta kerusakan infrastruktur dan lingkungan (Husna, 2012).

Bencana alam secara langsung memberikan dampak yang buruk, baik dalam lingkungan fisik, biologis, sosial dan dampak buruk pada kehidupan manusia dan Badan Nasional Penanggulangan Bencana melaporkan bahwa ada 2.175 kejadian bencana seperti longsor, gempa bumi dan banjir di Indonesia sejak awal tahun hingga 4 Desember 2017. Kejadian itu terdiri dari banjir dengan 737 kejadian, puting beliung dengan 651 kejadian, tanah longsor dengan 577 kejadian, kebakaran hutan dan lahan dengan 96 kejadian, banjir dan tanah longsor dengan 67 kejadian, kekeringan dengan 19 kejadian, gempa bumi dengan 18 kejadian, gelombang pasang atau abrasi dengan 8 kejadian serta letusan gunung api dengan 2 kejadian (Sartika, 2017). 
Kejadian bencana di Indonesia telah mencapai lebih dari 1.000 kali dalam setahun atau mencapai 3 kali dalam sehari. Kepala Pusat Data Informasi dan Humas BNPB Sutopo Purwo Nugroho mengatakan, sepanjang tahun 2017 telah terjadi 275 bencana yang menyebabkan 30 jiwa meninggal dan hilang, 66 jiwa luka, 153.183 menderita dan mengungsi, 10.254 unit rumah rusak, dan 92 bangunan fasilitas umum rusak. Bencana longsor paling banyak menimbulkan korban jiwa. Sejak 1 Januari 2018 sampai 7 Februari 2018 terdapat 19 orang meninggal dunia akibat longsor, sedangkan puting beliung 5 orang, banjir 3 orang, dan gempa 1 orang (Sugandi, 2010 \& Malia, 2018).

Bencana alam yang sering terjadi di Kota Bogor adalah longsor yang mana Kota Bogor berada pada dataran tinggi, sehingga masyarakatnya rawan untuk terkena longsor. Tanah longsor dapat kita artikan bahwa merupakan salah satu jenis gerakan massa tanah ataupun bebatuan atau bisa campuran dari tanah dan batu yang terganggunya kestabilan tanah atau penyusun lereng (Nurjanah dkk, 2011). Pada awal tahun 2018 longsor telah merusak rumah ataupun ladang-ladang diwilayah Kota Bogor dan menyebabkan 19 orang meninggal dunia dan pada tahun 2017 pun Sekretaris BPBD Kabupaten Bogor, Budi Pranowo mengatakan tingginya persentase bencana longsor dikarenakan adanya musim basah atau musim hujan dan fenomena lainnya serta curah hujan dengan intensitas ekstrim terjadi hampir merata di Kabupaten Bogor (Pryanka \& Rezkisari, 2018). Dari data yang telah didapat bisa dilihat kejadian longsor berisiko terjadinya peningkatan dan perlu diwaspadai.

Bencana yang telah terjadi akan selalu memberikan dampak bagi semua masyarakat. Adapun dampak personal meliputi korban meninggal dunia, sakit dan mengungsi. Dampak kerusakan, antara lain kerusakan rumah penduduk, gedung dan fasilitas pemerintah, fasilitas kesehatan, fasilitas ekonomi, fasilitas umum, kerusakan jalan dan kerusakan lahan serta kerusakan lainnya sehingga terdapat dampak negatif dari bencana terhadap biophysical systems dan human systems. Adapun dampak kerugian antara lain kerugian perdagangan, kerugian pertanian, peternakan dan perikanan, kerugian tidak bisa bekerja dan kerugian lainnya. Dampak dari bencana alam diduga dapat menyebabkan terhambatnya pertumbuhan ekonomi (Isa, 2016).

Perlu perhatian khusus pada lansia melalui aksi nyata, Kementrian Pemberdayaan Perempuan dan Perlindungan Anak melaksanakan Gerakan 1.000 Perempuan Peduli Bencana dan Lansia Merawat Lingkungan. Pada kondisi bencana, anak-anak dan kelompok rentan lainnya, seperti perempuan dan lansia menjadi korban paling banyak (1.000 Perempuan dan Lansia Waspada Bencana, 2017). Jumlah penduduk yang berpotensi terpapar longsor yaitu 40.9 juta jiwa, dimana balita yang berlokasi di daerah bahaya longsor tinggi ialah sebanyak 3.6 juta. Kemudian, sebanyak 39 ribu jiwa kelompok disabilitas berada dalam kategori bahaya yang tinggi. Sementara 284 ribu jiwa kelompok rentan berada dalam kategori bahaya sedang. Sebanyak 386 ribu jiwa kelompok lansia berada dalam kategori bahaya tinggi. Serta 2.8 juta jiwa lansia berada dalam kategori bahaya sedang (Fadhilah \& Aini, 2018). Hal tersebut juga sebagai bentuk perhatian dan komitmen Pemerintah untuk memperhatikan kelompok rentan, seperti perempuan dan lansia dengan meningkatkan pengetahuan dan kewaspadaan mereka apabila terjadi bencana (1.000 Perempuan dan Lansia Waspada Bencana, 2017). 
Berdasarkan fenomena dapat disimpulkan bahwa lansia memerlukan kesiapsiagaan dalam menghadapi bencana. Hal ini sangatlah penting, karena jika hanya pemerintahnya saja yang mendukung dan tidak ada dukungan dari masyarakat tidak akan berjalan dengan baik serta dalam keadaan menghadapi bencana sangat dibutuhkan masyarakat untuk mempersiapkan terjadinya bencana pada masa yang akan datang. Kesiapsiagaan bencana merupakan setiap aktivitas sebelum terjadinya bencana yang bertujuan untuk mengembangkan kapasitas operasional dan memfasilitasi respon yang efektif ketika terjadi suatu bencana (BNPB, 2008).

Pengetahuan secara teoritis merupakan hasil mengingat dari suatu kejadian, termasuk hal yang mengingatkan kejadian yang pernah dialami baik yang disengaja ataupun tidak disengaja dan kejadian ini terjadi setelah orang sudah melakukan kontak langsung atau pengamatan terhadap suatu hal tertentu. Pengetahuan yang baik yaitu didasari oleh beberapa faktor seperti pendidikan yang telah dicapainya, pekerjaan yang sedang dilakukan sekarang dan usia, apakah termasuk lansia, dewasa atau bahkan termasuk usia anak- anak (Budiman, 2013).

Hasil dari penelitian Saifuddin dkk (2015) mengatakan bahwa ada 64\% persentase jawaban responden yang menjawab tidak tahu dalam cara menyikapi jika terjadinya bencana. Maka lansia harus mengetahui tindakan yang akan dilakukan ketika menghadapi bencana, karena pengetahuan merupakan kunci utama yang dapat mempengaruhi sikap dan kepedulian masyarakat untuk siap serta siaga dalam menghadapi bencana. Lansia yang memiliki sikap yang baik adalah lansia yang siap dalam menghadapi bencana berdasarkan adanya pengetahuan yang baik terhadap tanda-tanda adanya bencana sehingga masyarakat selalu siaga melakukan pengungsian sewaktu-waktu. Dan bukan hanya pengetahuan saja yang penting dalam menghadapi bencana, sikap dalam menghadapi bencana sangatlah penting, karena sikap merupakan keadaan yang harus siap menghadapi suatu peristiwa yang sedang terjadi (Effendi dkk, 2015).

Sikap yang berarti dalam keadaan sehat dan siap melakukan tindakan atau siap menghadapi hal yang terjadi dan sikap dipandang sebagai kesiapan raga yang dapat diamati. Sikap membantu kita menginterpretasikan stimulus baru dan menampilkan respon yang sesuai ataupun sikap juga mampu mengarahkan orang lain untuk memberikan hal-hal yang positif terhadap diri sendiri atau pun masyarakat di sekitar (Sarwono, 2009). Berdasarkan penelitian Sugara dkk (2018) mengatakan bahwa sikap masyarakat atau kelompok rentan tergolong rendah. Hal ini terlihat pada rendahnya sikap mereka bahwa daerah yang mereka tinggali adalah daerah rawan, tidak menyimpan bahan makanan sebagai persediaan saat bencana, menganggap tidak penting dalam menghadapi bencana dan tidak memiliki kesiapan evakuasi saat terjadi bencana yang dapat datang tiba-tiba. Kurangnya pemahaman tentang karakteristik bahaya, sikap atau perilaku yang dapat mengakibatkan terjadinya penurunan sumber daya alam, kurangnya masyarakat tentang informasi peringatan dini yang dapat mengakibatkan ketidaksiapan masyarakat, dan ketidakberdayaan atau ketidakmampuan dalam menghadapi bencana tersebut (Effendi dkk, 2015).

Menurut peneliti pengetahuan tentang bencana seharusnya sudah diberikan kepada masyarakat khususnya lansia, karena pengetahuan sangat berpengaruh pada kehidupan masyarakat di masa depan dan masyarakatyang memiliki peran penting dalam keorganisasian di wilayah tersebut. Salah satu upaya 
pemerintah dalam meningkatkan keamanan terhadap bencana adalah mengembangkan pendidikan mengenai resiko bencana pada masyarakat. Sehingga hal ini mampu untuk memberikan kesadaran dan kesiapan masyarakat yang tinggal di daerah rawan bencana.

Kelurahan Baranangsiang merupakan salah satu kelurahan dari enam kelurahan yang ada di Kecamatan Bogor Timur dengan luas sekitar 235 hektar. Pembagian wilayah di Kelurahan Baranangsiang terdiri dari 14 RW dan 83 RT dan Kampung Babakan Peundeuy yaitu salah satu wilayah yang menjadi tempat penelitian. Wilayah Kampung Babakan Peundeuy terbagi menjadi 1 RW dan 6 RT, yang mana ada 4 RT yang dilakukan penelitian yaitu RT 01, RT 03, RT 04 dan RT 06. Setiap satu bulan sekali di Kampung Babakan Peundeuy rutin diadakannya posyandu lansia dengan jumlah lansia yang datang ke posyandu 50-70 lansia dari jumlah keseluruhan lansia yaitu 150 lansia dan Bencana longsor dan banjir terjadi secara merata di wilayah Kota dan Kabupaten Bogor, Senin 5 Februari 2018. Wilayah Kampung Babakan Pendeuy RT 06 RW 12, Kelurahan Baranangsiang, Kecamatan Bogor Timur, Kota Bogor terjadi rumah ambruk milik Bapak Atin 2 KK/9 jiwa, 1 balita, berdampak 2 bagian kamar tidur dan dapur. Selain menimbulkan kerugian material, longsor menyebabkan seorang korban jiwa, belasan korban luka dan beberapa orang lainnya dinyatakan hilang (Kotabogor.go.id).

Berdasarkan data diatas maka peneliti tertarik untuk melakukan penelitian dengan judul hubungan pengetahuan dan sikap dalam menghadapi bencana pada lansia di wilayah kampung babakan peundeuy Kota Bogor. Penelitian ini bertujuan untuk mengetahui adakah hubungan pengetahuan dan sikap pada lansia dalam menghadapi bencana di wilayah Kampung Babakan Peundeuy kota Bogor.

\section{METODE PENELITIAN}

Penelitian ini menggunakan metode kuantitatif deskriptif dan menggunakan desain cross sectional. Populasi dalam penelitian ini adalah semua lansia yang berada di wilayah Kampung Babakan Peundey Kota Bogor Pada Bulan Juli 2018. Jumlah sampel yang diambil untuk penelitian ini sebanyak 70 responden dengan menggunakan teknik pengambilan sampel yaitu purposive sampling. Penelitian ini dilaksanakan pada bulan juli 2018 di Kampung Babakan Peundeuy kota Bogor. Pemilihan tempat ini berdasarkan kejadian bencana yang belum lama terjadi di kota Bogor yaitu di wilayah Kampung Babakan Peundeuy RT 06 RW 12, Kelurahan Baranangsiang, Kecamatan Bogor Timur. Rumah ambruk milik warga sebanyak 2 rumah dan 9 korban

Tabel 1

Distribusi Responden berdasarkan usia di Wilayah Kampung Babakan Peundeuy Kota Bogor Tahun $2018(n=70)$

\begin{tabular}{cccccc}
\hline Variabel & N & Mean & Median & SD & Min-Max \\
\hline Usia & 70 & 54.31 & 53.50 & 6.854 & $45-73$
\end{tabular}

Berdasarkan tabel 1 didapatkan hasil yaitu rata-rata usia lansia 54.31 tahun dengan standar deviasi 6.854 tahun. Umur lansia termuda yaitu 45 tahun dan tertua 73 tahun. 
Tabel 2

Distribusi Responden berdasarkan jenis kelamin di Wilayah Kampung Babakan Peundeuy Kota Bogor Tahun $2018(n=70)$

\begin{tabular}{lcc}
\hline $\begin{array}{c}\text { Varia } \\
\text { bel }\end{array}$ & Frekuensi (n) & $\begin{array}{c}\text { Persentase } \\
(\boldsymbol{\%})\end{array}$ \\
\hline Jenis Kelamin & & \\
a. Laki-laki & 18 & 25,7 \\
b. Perempuan & 52 & 74,3 \\
\hline Total & $\mathbf{7 0}$ & $\mathbf{1 0 0}$ \\
\hline
\end{tabular}

Berdasarkan tabel 2 menunjukan bahwa sebagian besar responden berjenis kelamin perempuan yaitu dengan jumlah responden $52(74,3 \%)$.

Tabel 3

Distribusi Responden berdasarkan pendidikan di Wilayah Kampung Babakan Peundeuy Kota Bogor Tahun $2018(\mathbf{n}=70)$

\begin{tabular}{lcc}
\hline \multicolumn{1}{c}{ Variabel } & Frekuensi (n) & Persentase (\%) \\
\hline Pendidikan & & \\
a. Tinggi (SMA - Perguruan Tinggi) & 22 & 31,4 \\
b. Rendah (SD - SMP) & 48 & 68,6 \\
\hline Total & $\mathbf{7 0}$ & $\mathbf{1 0 0}$ \\
\hline
\end{tabular}

Berdasarkan tabel 3 diatas sebagian besar responden berpendidikan rendah yaitu (SD - SMP) dengan jumlah 48 responden $(68,6 \%)$.

Tabel 4

Distribusi Responden berdasarkan pekerjaan di Wilayah Kampung Babakan Peundeuy Kota Bogor Tahun $2018(n=70)$

\begin{tabular}{|c|c|c|}
\hline Variabel & Frekuensi (n) & Persentase (\%) \\
\hline Pekerjaan & & \\
\hline a. Bekerja & 19 & 27,1 \\
\hline b. Tidak bekerja & 51 & 72,9 \\
\hline Total & 70 & 100 \\
\hline
\end{tabular}

Berdasarkan tabel 4 menyatakan bahwa mayoritas responden tidak bekerja dengan jumlah 51 responden $(72,9 \%)$.

Tabel 5

Gambaran Responden berdasarkan pengetahuan lansia di Wilayah Kampung Babakan Peundeuy Kota Bogor Tahun $2018(n=70)$

\begin{tabular}{|c|c|c|}
\hline Kategorik & Frekuensi & Presentase (\%) \\
\hline Kurang baik & 47 & 67.1 \\
\hline Baik & 23 & 32.9 \\
\hline Total & 70 & 100.0 \\
\hline
\end{tabular}

Berdasarkan tabel 5 hasil penelitian pengetahuan lansia menunjukan bahwa sebagian besar responden kurang baik yaitu $(67.1 \%)$ dengan jumlah 47 responden. 
Tabel 6

Gambaran Responden berdasarkan sikap lansia di Wilayah Kampung Babakan Peundeuy Kota Bogor Tahun $2018(n=70)$

\begin{tabular}{ccc}
\hline Kategorik & Frekuensi & Presentase (\%) \\
\hline Kurang baik & 44 & 62.9 \\
\hline Baik & 26 & 37.1 \\
\hline Total & $\mathbf{7 0}$ & $\mathbf{1 0 0 . 0}$ \\
\hline
\end{tabular}

Berdasarkan tabel 6 hasil penelitian sikap lansia menunjukan bahwa sebagian besar responden kurang baik yaitu $(62.9 \%)$ dengan jumlah 44 responden.

Tabel 7

Hubungan pengetahuan dan sikap dalam menghadapi bencana pada lansia di Wilayah Kampung Babakan Peundeuy Kota Bogor Tahun 2018 (n=70)

\begin{tabular}{|c|c|c|c|c|c|c|c|c|}
\hline \multirow{3}{*}{\multicolumn{2}{|c|}{$\begin{array}{l}\text { Variabel } \\
\text { Kategori }\end{array}$}} & \multicolumn{4}{|c|}{ Sikap Lansia } & \multirow{2}{*}{\multicolumn{2}{|c|}{$\begin{array}{c}\text { Jumlah } \\
\text { OR 95\% }\end{array}$}} & \multirow[t]{3}{*}{ P value } \\
\hline & & \multicolumn{2}{|c|}{ Baik } & \multicolumn{2}{|c|}{$\begin{array}{c}\text { Kurang } \\
\text { Baik }\end{array}$} & & & \\
\hline & & $\mathbf{N}$ & $\%$ & $\mathbf{N}$ & $\%$ & $\mathbf{N}$ & $\%$ & \\
\hline \multirow[t]{3}{*}{$\begin{array}{l}\text { Pengetahuan } \\
\text { Lansia }\end{array}$} & Baik & 14 & 53.8 & 12 & 46.2 & 26 & 100 & $\begin{array}{c}4.5370 .004(1.566- \\
13.142)\end{array}$ \\
\hline & $\begin{array}{c}\text { Kurang } \\
\text { Baik }\end{array}$ & 9 & 20.5 & 35 & 79.5 & 44 & 100 & \\
\hline & Total & 23 & 32.9 & 47 & 67.1 & 70 & 100 & \\
\hline
\end{tabular}

Berdasarkan tabel 7 presentasi pengetahuan lansia yang kurang baik dengan sikap yang kurang baik mayoritas 35 orang $(79.5 \%)$. p value yang dihasilkan adalah 0.004 yang artinya ada hubungan antara pengetahuan dan sikap. Nilai OR yang dihasilkan 4.537 yang artinya 4,5 kali lebih tinggi peluang kejadian pengetahuan yang kurang baik dan sikap yang kurang baik dalam menghadapi bencana.

\section{PEMBAHASAN}

\section{Karakteristik Responden}

Berdasarkan hasil penelitian ini dari perhitungan secara uji statistik yaitu didapatkan rata- rata usia lansia 54.31 tahun dengan standar deviasi 6.854 tahun. Umur lansia termuda yaitu 45 tahun dan tertua 73 tahun. Setelah melewati usia (40-60 tahun), daya tangkap dan pola pikir seseorang akan menurun (Wawan \& Dewi, 2011). Pada lansia, sistem saraf pusat telah mengalami beberapa perubahan seperti pada otak lansia, yang mana pada lansia akibat penuaan, otak kehilangan 100.000 neuron. Neuron dapat mengirimkan signal kepada beribu-ribu sel lain dengan kecepatan $200 \mathrm{mil} / \mathrm{jam}$. Terjadi penebalan atropi cerebral dengan berat otak menurun $100 \%$ antara usia 30-70 tahun. Secara berangsur-angsur tonjolan dendrit dineuron hilang dan disusul membengkaknya batang dendrit dan batang sel secara progresif terjadi fragmentasi dan kematian sel. Pada semua sel terdapat deposit lipofusin yang terbentuk di sitoplasma, kemungkinan berasal dari lisosom atau mitokondria. RNA, Mitokondria dan enzyme sitoplasma menghilang, inklusi dialin eosinofil dan badan lewy, neurofibriler menjadi kurus dan degenerasi granulovakuoler. Corpora amilasea terdapat dimana-mana dijaringan otak. Berbagai perubahan degeneratif ini meningkat pada individu lebih dari 20 tahun yang menyebabkan gangguan persepsi dan analisis lalu input sensorik menurun 
Menyebabkan gangguan kesadaran sensorik nyeri sentuh, panas, dingin dan posisi sendi (Darmojo, 2009). Sehingga lansia menjadi kurang memahami pengetahuan, salah satunya pengetahuan dalam menghadapi bencana.

Penelitian ini sesuai dengan hasil penelitian Hamdani \& Satria (2017) yang berjudul Faktor-Faktor Yang Mempengaruhi Pengetahuan Manajemen Resiko Bencana Gempa Bumi Pada Kelompok Lansia Di Desa Lampulo Kecamatan Kuta Alam Kota Banda Aceh yaitu didapatkan hasil tertinggi ialah usia yang dimulai dari 60-74 tahun sebanyak 63 orang lansia $(81,8 \%)$. Penelitian ini pun sejalan dengan penelitian Damayanti dkk (2017) yang berjudul Hubungan Pengetahuan Tentang Manajemen Bencana Dengan Prevention Masyarakat Dalam Menghadapi Bencana Gunung Meletus Pada Kepala Keluarga Di Rt 06/Rw 01 Dusun Puncu Desa Puncu Kecamatan Puncu-Kediri, bahwa hampir sebagian besar lansia berumur $>40$ tahun dengan jumlah 21 orang (64\%). Hal ini dapat dilihat dari beberapa indikator antara lain adalah banyaknya kepala keluarga yang memiliki ketergantungan pada anak atau keluarga lainnya, selain kurang produktif, dari segi pendidikan ditemukan bahwa lansia yang berusia $>40$ tahun itu berpendidikan rendah dan karena rendahnya tingkat pendidikan ini berkorelasi positif dan signifikan dengan kurang baiknya sosial ekonomi, kondisi kesehatan dan kemandiriannya.

Menurut analisis peneliti dapat disimpulkan bahwa seseorang yang memasuki usia 45 - 74 tahun akan mengalami penurunan fungsi organ tubuhnya serta fungsi sistem saraf berubah dengan bertambahnya usia. Pada penelitian Maryati (2013) yang berjudul gambaran fungsi kognitip lansia di UPT Panti Werdha Mojopahit Kabupaten Mojokerto yang menjelaskan bahwa fungsi tubuh pada lanjut usia, seperti kekuatan atau tenaganya turun sebesar $88 \%$, fungsi penglihatan menurun, dan pada sistem muskuloskeletal menyebabkan penurunan fleksibilitas otot dan sendi, penurunan fungsi kartilago, berkurangnya kepadatan tulang, penurunan kekuatan otot dan berkurangnya massa otak progresif akibat berkurangnya sel saraf yang tidak bisa diganti. Pada lanjut usia, daya ingat merupakan salah satu fungsi kognitif yang sering kali mengalami penurunan. Berbagai jenis gangguan kognitif yang dialami seperti mudah lupa, disorientasi terutama dalam hal wakru, gangguan pada kemampuan pendapat dan pemecahan masalah. Sehingga usia mempengaruhi ingatan lansia dan harus dilakukannya hal yang mampu mengasah kognitif lansia.

Hasil penelitian ini menunjukan bahwa sebagian besar lansia berjenis kelamin perempuan yaitu 52 orang lansia (74, 3\%). Pendekatan sosial jenis kelamin dan literatur dari Gillgan (1982) dalam Carter (2011), lakilaki dan perempuan mengevaluasi dilema etis secara berbeda, jika perempuan lebih menggunakan perasaannya jika laki-laki lebih sering menggunakan logikanya. Dalam penelitian Nurhidayati dan Bahar (2018) yang berjudul Dukungan Keluarga Meningkatkan Kesiapsiagaan Lansia Dalam Menghadapi Bencana Gunung Berapi pada bulan Januari menjelaskan bahwa didalam penelitiannya mendapatkan lansia terbanyak berjenis kelamin perempuan yaitu sebanyak (63,5\%) dan mengatakan bahwa angka harapan hidup perempuan adalah 73 tahun dan laki-laki 69 tahun.

Berdasarkan rata-rata angka harapan hidup secara nasional, usia harapan hidupnya dipengaruhi oleh tiga faktor utama yaitu makanan, lingkungan dan stress, yang membedakan hanya tingkat level stress yang dialami pria, umumnya lebih tinggi dibandingkan dengan yang dialami perempuan. Karena, dalam tradisi 
kehidupan masyarakat di seluruh dunia para laki-laki adalah kepala rumah tangga yang bertanggung jawab untuk menafkahi keluarga (Badan Pusat Statistik, 2018).

Penelitian ini sejalan dengan penelitian yang dilakukan oleh Hamdani \& Satria (2017) yang berjudul FaktorFaktor Yang Mempengaruhi Pengetahuan Manajemen Resiko Bencana Gempa Bumi Pada Kelompok Lansia Di Desa Lampulo Kecamatan Kuta Alam Kota Banda Aceh yaitu didapatkan hasil Frekuensi jenis kelamin tertinggi adalah perempuan sebanyak 40 orang (51,9\%) dan menurut Fatimah (2008) kelompok perempuan adalah termasuk kelompok masyarakat yang memiliki derajat kerentanan yang sangat tinggi, karena ketika dihadapkan dengan bencana yang banyak dipengaruhi oleh faktor salah satunya adalah perbedaan akses dan kontrol terhadap sumber daya sehingga akses dan kontrol terhadap sumber daya dibutuhkan oleh individu untuk bertahan hidup, dan memulihkan diri dari kondisi pasca bencana. Dapat disimpulkan bahwa terlepas dari dampaknya yang besar dan menyeluruh, tiap-tiap individu tentu memiliki pengalaman yang berbeda ketika berhadapan dengan bencana. Hal tersebut terjadi karena masing-masing individu memiliki derajat kerentanan dan kapasitas penanggulangan bencana yang berbeda, antara satu dengan lainnya.

Berdasarkan hasil uji statistik hasil penelitian ini menunjukan sebagian besar rlansia berpendidikan rendah (SMP-SD) yaitu sebanyak 48 orang $(68,6 \%)$. Carter (2011) mengatakan bahwa semakin tinggi pendidikan seseorang akan semakin mudah menerima informasi sehingga semakin banyak pula pengalaman yang dimiliki dan Wawan \& Dewi (2011) menjelaskan bahwa tingkat pendidikan dapat menentukan tingkat kemampuan seseorang dalam memahami dan menyerap pengetahuan yang telah diperoleh.

Hasil penelitian ini didukung ole Eberhardt dkk (2008) yang melakukan penelitian dengan judul Long-term investigation of a deep-seated creeping landslide in crystalline rock. Part II. Mitigation measures and numerical modelling of deep drainage at Campo Vallemaggia terhadap 74 responden dengan latar belakang pendidikan yang berbeda bahwa hasilnya adalah mereka yang memiliki pendidikan dengan level lebih tinggi pasti memiliki pengetahuan yang luas dan pengalaman yang banyak dan hal ini juga berpengaruh terhadap kemampuan kognitif seseorang. Dari hasil penelitian dapat disimpulkaan bahwa mayoritas lansia berpendidikan rendah (SD - SMP) dengan sebagian besar lansia berusia 45-74 tahun. Jika semakin tingginya pendidikan lansia maka pengetahuan dan sikap dalam menghadapi bencana akan menjadi baik dalam menanggapi dan menyikapinya.'Setelah dilakukan pengolahan dan analisa data diketahui bahwa untuk distribusi pekerjaan pada lansia di Wilayah Kampung Babakan Peundeuy Kota Bogor Tahun 2018 lebih banyak lansia yang tidak bekerja yaitu sebanyak 51 orang (72,9\%). Menurut teori Wawan \& Dewi (2011) pekerjaan merupakan suatu cara mencari nafkah yang banyak tantangan. Pekerjaan dilakukan untuk menunjang kehidupan pribadi maupun keluarga.

Penelitian ini sejalan dengan penelitian yang dilakukan oleh Mendrofa (2012) dengan judul hubungan pengetahuan dan sikap lansia dalam aplikasi kesiapsiagaan bencana di Kota Medan yang menjelaskan bahwa pekerjaan seseorang akan berpengaruh terhadap pengetahuan dan pengalamannya karena ada pekerjaan yang lebih sering menggunakan otaknya dibandingkan dengan ototnya. Kinerja dan kemampuan otak seseorang dalam menyimpan daya ingat akan meningkat ketika sering digunakan dan akan bertambah ketika sering digunakan untuk beraktifitas dan mengerjakan sesuatu dalam bentuk teka- teki ataupun penalaran. 
Menurut analisis peneliti dapat disimpulkan bahwa jika lansia memiliki pekerjaan didalam kehidupannya sehari-hari maka akan sangat baik untuk mempengaruhi pengetahuan dan pengalaman dalam hidupnya sehingga lansia dapat memiliki wawasan yang luas, dimana lansia nantinya akan lebih baik dalam memahami hidup ini. Termasuk dalam memahami sebuah pengetahuan, seperti pengetahuan terkait dengan kebencanaan.

\section{Gambaran Pengetahuan Lansia}

Hasil penelitian ini menunjukan bahwa sebagian lansia berpengetahuan kurang baik yaitu 47 orang $(67,1 \%)$. Pengetahuan selalu dijadikan sebagai awal dari sebuah tindakan dan kesadaran seseorang, sehingga dengan kapasitas pengetahuan diharapkan bisa menjadi dasar dari tindakan seseorang. Reber (2010) mengemukakan bahwa pengetahuan adalah kumpulan informasi yang dimiliki oleh seseorang atau kelompok, atau budaya tertentu yang didapat dari pengBerdasarkan penelitian Damayanti dkk (2017) pengetahuan seseorang biasanya diperoleh dari pengalaman yang berasal dari berbagai macam sumber contohnya seperti media masa, media elektronik, buku petunjuk, petugas kesehatan, media poster, kerabat dekat dan sebagainya. Pengetahuan ini dapat membantu keyakinan tertentu sehingga seseorang berperilaku sesuai keyakinan tersebut. Menurut peneliti pengetahuan lansia sangatlah penting untuk ditingkatkan, karena sangat membantu lansia dalam kehidupan sehari- harinya dan perlu ditingkatkan kesadarannya dalam kebencanaan. Sehingga lansia lebih mengetahui kebencanaan, salah satunya cara menghadapi bencana.

\section{Gambaran Sikap Lansia}

Randi dalam Imam (2011) sikap merupakan sebuah evaluasi umum yang dibuat manusia terhadap dirinya sendiri atau orang lain atas reaksi atau respon terhadap stimulus (objek) yang menimbulkan perasaan yang disertai dengan tindakan yang sesuai dengan objeknya. Hasil penelitian ini menunjukan bahwa sikap lansia sebagian besar kurang baik yaitu (62.9\%) dengan jumlah 44 responden.Hasil penelitian dari Ananto (2015) menunjukkan bahwa kesiapsiagaan masyarakat pada tahap pra bencana tergolong rendah, bahkan menurut narasumber atau tokoh masyarakat tergolong sangat rendah. Pada tahap bencana atau tanggap darurat dan pasca bencana atau rekonstruksi dan rehabilitasi tergolong sedang. Kesiapsiagaan terhadap bencana yang masih pada kisaran rendah-sedang tersebut perlu ditingkatkan agar pada masa yang akan datang masyarakat lebih siaga dan bahkan tangguh dalam menghadapi bencana. Dan menjadi daerah yang siaga dan bahkan menjadi desa tangguh bencana. Berdasarkan data diatas dapat disimpulkan bahwa sikap yang baik tentunya akan memberikan pengaruh yang baik bagi pengetahuan lansia, sehingga perlu ditingkatkan kembali sikap lansia dalam menghadapi bencana, agar menjadi lansia yang memiliki sikap yang baik.

\section{Hubungan pengetahuan dan sikap dalam menghadapi bencana pada lansia}

Pada penelitian ini prosentasi pengetahuan lansia yang kurang baik dengan sikap yang kurang baik mayoritas 35 orang $(79.5 \%)$. p value yang dihasilkan adalah 0.004 yang artinya ada hubungan antara pengetahuan dan sikap. Nilai OR yang dihasilkan 4.537 yang artinya 4,5 kali lebih tinggi peluang kejadian pengetahuan yang kurang baik dan sikap yang kurang baik dalam menghadapi bencana.

/Hasil penelitian ini sejalan dengan Pembriati (2013) yang menjelaskan bahwa pengetahuan merupakan hasil tahu dan terjadi setelah orang melakukan penginderaan terhadap suatu objek tertentu. Penelitian ini sejalan 
dengan penelitian Halis (2018) dengan judul hubungan pengetahuan dengan sikap kesiapsiagaan lansia menghadapi banjir di Kabupaten Konawe yaitu didapatkan nilai $p=0.002$ yang artinya memiliki hubungan yang signifikan pengetahuan dengan sikap kesiapsiagaan pada lanjut usia menghadapi banjir di Kabupaten Konawe. Sikap ialah suatu mental dan saraf yang berhubungan dengan kesiapan untuk menanggapi seperti diorganisasi melalui pengalaman dan memiliki pengaruh yang mengarahkan terhadap perilaku. Sikap yaitu mempelajari kecenderungan yang memberikan tanggapan terhadap suatu objek, baik yang disenangi atau tidak disenangi secara konsisten (Setiadi, 2013).

Berdasarkan hasil penelitian Saifuddin dkk (2015) dalam judul Analisis Tingkat Kesiapsiagaan Kelompok Rentan Dalam Menghadapi Bencana Banjir Di Kecamatan Meurebo Kabupaten Aceh Barat menjelaskan bahwa ada $64 \%$ persentase jawaban yang menjawab tidak tahu dalam cara menyikapi jika terjadinya bencana. Hasil yang didapatkan dari wawancara dengan masyarakat, bahwa sebagian besar masyarakat ada yang belum pernah mengikuti pelatihan bencana dan terkadang jika ada penyuluhan kesehatan masyarakat tidak datang untuk menghadirinya. Maka dari itu lansia harus mengetahui tindakan yang akan dilakukan ketika menghadapi bencana, karena pengetahuan merupakan kunci utama yang dapat mempengaruhi sikap dan kepedulian masyarakat untuk siap serta siaga dalam menghadapi bencana.

Pengetahuan yang dimaksud dalam penelitian ini adalah pengetahuan dalam menghadapi bencana pada lansia dan sikap adalah sebuah tindakan lansia terhadap suatu stimulus atau rangsangan yang diberikan oleh seseorang, benda asing, berupa respons atau tanggapan sebagai reaksinya. Sikap merupakan sesuatu yang dipelajari dan sikap menentukan bagaimana individu bereaksi terhadap suatu situasi serta menentukan apa yang dicari individu dalam kehidupan (Slameto, 2010).

Menurut analisis peneliti dapat disimpulkan bahwa ada hubungan antara pengetahuan dan sikap dalam menghadapi bencana pada lansia di Wilayah Kampung Babakan Peundeuy Kota Bogor Tahun 2018. Hasil penelitian ini menunjukan bahwa lansia dengan pengetahuan yang kurang, maka akan kurang pula lansia dalam menyikapi terjadinya bencana. Pada lansia pengetahuan dan sikap ini sangatlah penting untuk menjadi dasar seseorang sehingga dapat melakukan suatu respon atau tanggapan yang baik dalam menghadapi bencana nantinya.

\section{KESIMPULAN DAN REKOMENDASI}

Berdasarkan hasil penelitian dan pembahasan maka dapat ditarik kesimpulan yaitu karakteristik responden, sebagian besar proporsi responden yaitu perempuan lebih besar jumlahnya dibandingkan laki-laki. Berada pada rentang usia secara keseluruhan empat puluh lima sampai tujuh puluh empat tahun atau sebesar sembilan puluh lima koma tujuh persen. Dilihat dari pendidikan sebagian besar berpendidikan SMP dan SD. Sedangkan sebagian besar responden tidak bekerja. Proporsi pengetahuan responden sebagian besar dikategorikan kurang. Gambaran pengetahuan dan sikap lansia dalam menghadapi bencana yaitu kurang baik. Terdapat hubungan bermakna dengan nilai $\mathrm{p}$ value kurang dari nol koma nol lima antara pengetahuan dan sikap dalam menghadapi bencana pada lansia di Wilayah Kampung Babakan Peundeuy Kota Bogor.

Bagi institusi pendidikan diharapkan untuk dapat menyediakan lebih banyak lagi buku sumber dan literature 
terutama mengenai penelitian tentang kebencanaan dan diharapkan selalu diadakannya pelatihan kebencanaan. Bagi petugas kesehatan diharapkan dapat memotivasi dan dapat merencanakan untuk lansia, sehingga dapat melakukan program peningkatan pengetahuan dengan mengadakan suatu pelatihan untuk meningkatkan upaya-upaya yang harus dilakukan ketika adanya bencana. Bagi masyarakat diharapkan mengikuti pelatihan kebencanaan sehingga mampu menyikapi bencana dengan baik sehingga menyadari bahwa betapa pentingnya masyarakat mengetahui mekanisme dan mengetahui hambatan yang terjadi dalam menghadapi bencana. Hasil penelitian ini menjadi dasar bagi penelitian selanjutnya dan hendaknya menambahkan jumlah sampel dan lokasi penelitian. Penelitian selanjutnya diharapkan tidak hanya menghubungan pengetahuan dalam menghadapi bencana tetapi dapat menghubungkan acute response (tanggap darurat) dalam menghadapi bencana.

\section{DAFTAR PUSTAKA}

1. 1.000 Perempuan dan Lansia Waspada Bencana. (2017).

Https://Ambon.Antaranews.Com/Berita/41046/1000-Perempuan-Dan-Lansia- Waspada-Bencana.

2. Ananto. (2015). Kesiapsiagaan Lansia Dalam Menghadapi Bencana Banjir Bandang Di Kecamatan Welahan Kabupaten Jepara. Indonesian Journal of Conservation from file:///E:/journal/kesiapsiagaan.pdf Di Akses pada 09/04/2018.

3. Badan Pusat Statistik. (2018). Kecamatan kemalang dalam angka kemalang in figure 2018. Kemalang: BPS Kabupaten Klaten. From http://www.klatenkab.bps.go.id . Diakses pada tanggal $22 / 08 / 2018$.

4. BNPB. (2008). Pedoman Umum Persiapan Resiko Bencana. Jakarta: BNPB.

5. BNPB. (2010). Buku panduan pengenalan karakteristik bencana dan upaya mitigasinya di Indonesia. Jakarta: BNPB.

6. BNPB. (2017). Potensi dan Ancaman Bencana. https://www.bnpb.go.id/home/potensi. Diakses Pada Tanggal 04/06/2018.

7. Budiman. (2013). Kapita Selekta Kuisioner Pengetahuan Dan Sikap Dalam Penelitian Kesehatan. Jakarta: Salemba Medika.

8. Carter. (2011). Disaster Manegement: A Disaster Manager's Handbook. Manila: ADB. CRED. (2012). Pervention Web. The United Nations Office of Disaster Risk Reduction. From http://www.preventionweb.net/countries/idn/data/ diakses pada tanggal 11/04/2018.

9. Damayanti, dkk. (2017). Hubungan Pengetahuan Tentang Manajemen Bencana Dengan Prevention Masyarakat Dalam Menghadapi Bencana Gunung Meletus Pada Kepala Keluarga Di Rt 06/Rw 01 Dusun Puncu Desa Puncu Kecamatan Puncu-Kediri. Jurnal Ilmu Kesehatan Vol. 5 No. 2, Mei 2017. file:///C:/Users/Administrator/Downloads/document\%20(1).pdf Diakses Pada Tanggal 06/04/2018.

10. Darmojo. 2009. Teori Proses Menua. Jakarta: Pusat Penerbitan Departemen Ilmu Penyakit Dalam Fakultas Kedokteran Universitas Indonesia.

11. Eberhardt. (2008). Long-Term Investigation Of A Deep-Seated Creeping Landslide In Crystalline Rock. Part II. Mitigation Measures And Numerical Modelling Of Deep Drainage At Campo 
Vallemaggia. Canadian Geotechnical Journal. Diakses pada tanggal 16/08/2018.

12. Effendi, dkk. (2015). Pengaruh Pengetahuan Dan Sikap Terhadap Kesiapsiagaan Masyarakat Dalam Menghadapi Bencana Banjir Di Desa Perkebunan Bukit Lawang Kecamatan Bahorok Tahun 2011. Jurnal Ilmiah

Keperawatan.file:///E:/Jurnal\%20Ilmiah\%20Keperawatan\%20muchtar\%20pengeta huan\%20dan\%20sikap.pdf di akses pada tanggal 07/04/2018.

13. Hamdani \& Satria. (2017). Faktor-Faktor Yang Mempengaruhi Pengetahuan Manajemen Resiko Bencana Gempa Bumi Pada Kelompok Lansia Di Desa Lampulo Kecamatan Kuta Alam Kota Banda Aceh. Jurnal Ilmiah Keperawatan. From file://C:/Users/Administrator/Downloads/432314390-1-PB.pdf Diakses pada tanggal 16/08/2018.

14. Husna. (2012). Faktor-Faktor Yang Mempengaruhi Kesiapsiagaan Bencana Di RSUDZA Banda Aceh. Influencing Factors on Disaster Preparedness in RSUDZA Banda Aceh. Idea Nursin Journal. From http://www.jurnal.unsyiah.ac.id/INJ/article/view/1578 Diakses Pada Tanggal $06 / 04 / 2018$.

15. Imam. (2011). Aplikasi Analisis Multivariate dengan Program IBM SPSS 19. Badan Penerbitan Universitas Diponegoro, Semarang.

16. Isa. (2016). Bencana Alam: Berdampak Positif Atau Negatif Terhadap Pertumbuhan Ekonomi? $\begin{array}{llllll}\text { The } 3 r d & \text { University } & \text { Research } & \text { Colloquium }\end{array}$ file:///E:/Jurnal\%20Ilmiah\%20Keperawatan\%20dampak\%20bencana\%20u\%20eko nnomi.pdf di akses pada tanggal 14/04/2018.

17. Malia. (2018). BNPB: 30 Orang Meninggal Akibat Bencana Sepanjang 2018. From https://www.idntimes.com/news/indonesia/indianamalia/bnpb-30-orangmeninggal- akibatbencana-sepanjang-1/full diakses pada tangḡal 11/04/2018.

18. Maryati, dkk. (2013). Gambaran Fungsi Kognitif Pada Lansia Di Upt Panti Werdha Mojopahit Kabupaten Mojokerto. From http://stikespemkabjombang.ac.id/ejurnal/index.php/April2013/article/view/17/15

19. Nurhidayati dan Bahar. (2018). Dukungan Keluarga Meningkatkan Kesiapsiagaan Lansia Dalam Menghadapi Bencana Gunung Berapi. Jurnal Keperawatan Respati Yogyakarta. From http://nursingjurnal.respati.ac.id/index.php/JKRY/index. Diakses pada tanggal 22/08/2018.

20. Nurjanah, dkk. (2011). Manajemen Bencana. Bandung: Alfabeta.

21. Pembriati. (2013). Pengaruh Model Pembelajaran Terpadu Pada Pengintegrasian Materi Pengurangan Risiko Bencana Dalam Mata Pelajaran IPS SMP Terhadap Pengetahuan Dan Kesiapsiagaan Bencana. Dalam Jurnal Bumi Lestari, Vol. 1 No. 1, September 2013, Hal, 1-8. Surakarta: UNS. 
22. Pryanka \& Rezkisari. (2018). Longsor, Bencana Tertinggi di Kabupaten Bogor. News. Fromhttp://www.republika.co.id/berita/nasional/jabodetabeknasional/18/01/02/p1m $\quad 9 q 328$ longsor-bencana-tertinggi-di-kabupaten-bogor Di Akses Pada Tanggal 14/04/2018.

23. Saifuddin, dkk. (2015). Analisis Tingkat Kesiapsiagaan Kelompok Rentan Dalam Menghadapi Bencana Banjir Di Kecamatan Meurebo Kabupaten Aceh Barat. Jurnal Ilmu Kebencanaan (JIKA). file:///C:/Users/Administrator/Downloads/5622- 11377-1-SM.pdf di akses pada tanggal 03/06/2018.

24. Sartika. (2017). Hati-hati Cuaca Ekstrem, Siaga Selama 3 Hari ke Depan. Fromhttps://sains.kompas.com/read/2017/11/28/133822023/hati-haticuacaekstrem- siaga-selama3-hari-ke-depan. diakses pada tanggal 11/04/2018.

25. Sarwono. (2009). Psikologi Remaja. Jakarta: Grafindo Persada.

26. Setiadi. (2013). Perilaku Konsumen. Edisi Pertama. Jakarta: PT. Prenada Media. Slamet.(2010). Belajar Dan Faktor-Faktor Yang Mempengaruhinya. Jakarta: Rineka Cipta.

27. Sugandi. (2010). Pengetahuan dan pengurangan resiko bencana. From http://sigap bencana.com. Diakses pada tanggal 11/04/2018.

28. Sugara, dkk. (2018). Hubungan Pengetahuan Dengan Sikap Kesiapsiagaan Masyarakat Menghadapi Erupsi Gunung Kelud Pada Fase Mitigasi. Nursing News Volume 3,

Nomor1,2018.Fromfile:///E:/Journal/Alatas\%20Sofan\%20Sugara1\%20SM\%20peg etahuan\%20sikap\%202\%20kelud.pdf 07/04/2018.

29. Wawan \& Dewi. (2011). Teori dan Pengukuran Pengetahuan, Sikap, dan Perilaku. Manusia. Cetakan II. Yogyakarta: Nuha Medika. 